
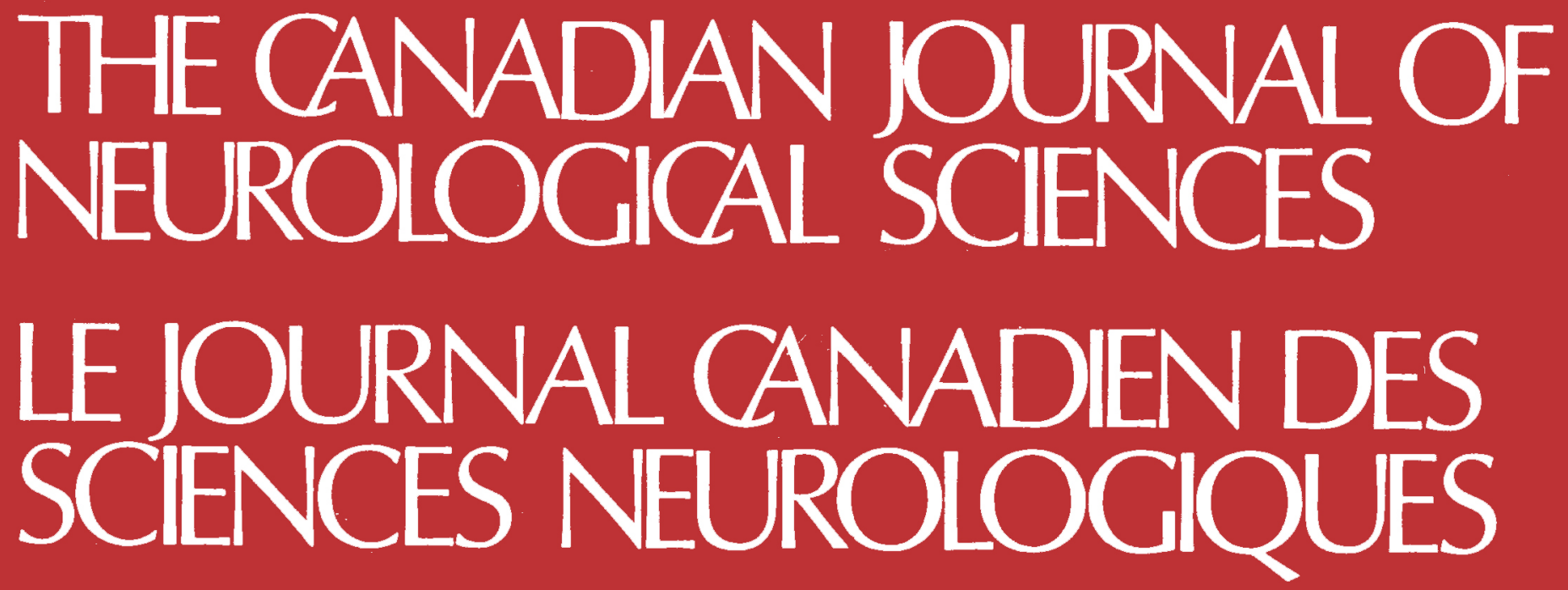

Spongiform Encephalopathy of Long Duration:

A Family Study ........... G.P.A. Rice, D.W. Paty, M.J. Ball, R. Tatham, and A. Kertesz

Giant Axonal Neuropathy: Visual and Oculomotor

Deficits ............................ T.H. Kirkham, D. Guitton and S.G. Coupland

Migraines Inhabituelles ................................... Louis E. Roy

Bilateral Encephaloclastic Lesions in a 26 Week Gestation Fetus:

Effect on Neuroblast Migration ............................ Margaret G. Norman

The Relationship Between Cerebral Blood Flow and the

EEG in Normals .................... Devidas Menon, Zoltan Koles and Allen Dobbs

EMG Biofeedback in Patients with Motor Disorders: An Aid for Coordinating

Activity in Antagonistic Muscle Groups ............. Alan E. Davis and Robert G. Lee

Motor Radiculopathy - An Unusual Presentation of

Multiple Sclerosis .........................J.H. Noseworthy and L.P.M. Heffernan

University of Toronto Neurosurgical Rounds No. 3

Normal Pressure Hydrocephalus - High Pressure

Normocephalus Hart Shutz, J.F.R. Fleming, R.P. Humphreys, J.H.N. Deck and William S. Keith

Scar Prevention in Peripheral Nerve Surgery .................. Fraser W. Saunders

Gradient of Interference by Various Frequencies on $60 \mathrm{~Hz}$ Kindling ....... John Gaito

Abstracts of Third Annual Meeting of Canadian Congress of

Neuropsychopharmacology

The Benzodiazepine Receptor: The Pharmacology of Emotion ......... H.A. Robertson

Interactions Between the Benzodiazepines, Methylxanthines and

Adenosine ........................................... Phillis and P.H. Wu

Organization of GABA-Containing Neurons in Some Extrapyramidal Nuclei H.C. Fibiger

Use of a Synaptosomal Model to Monitor Drug-Induced In Vivo

Changes in the $\gamma$-Aminobutyric Acid Content of Nerve Endings and

Its Relevance to Research on Antipsychotic Drugs ................... J.D. Wood

GABA and Neuropsychiatric Disorders

S.J. Enna

\title{
Abstracts of Third Annual Meeting of Canadian Congress of Neuropsychopharmacology
}

Official Journal of the Canadian Neurological Society, the Canadian Neurosurgical Society and the Canadian Society of Electroencephalographers, Electromyographers and Clinical Neurophysiologists. 

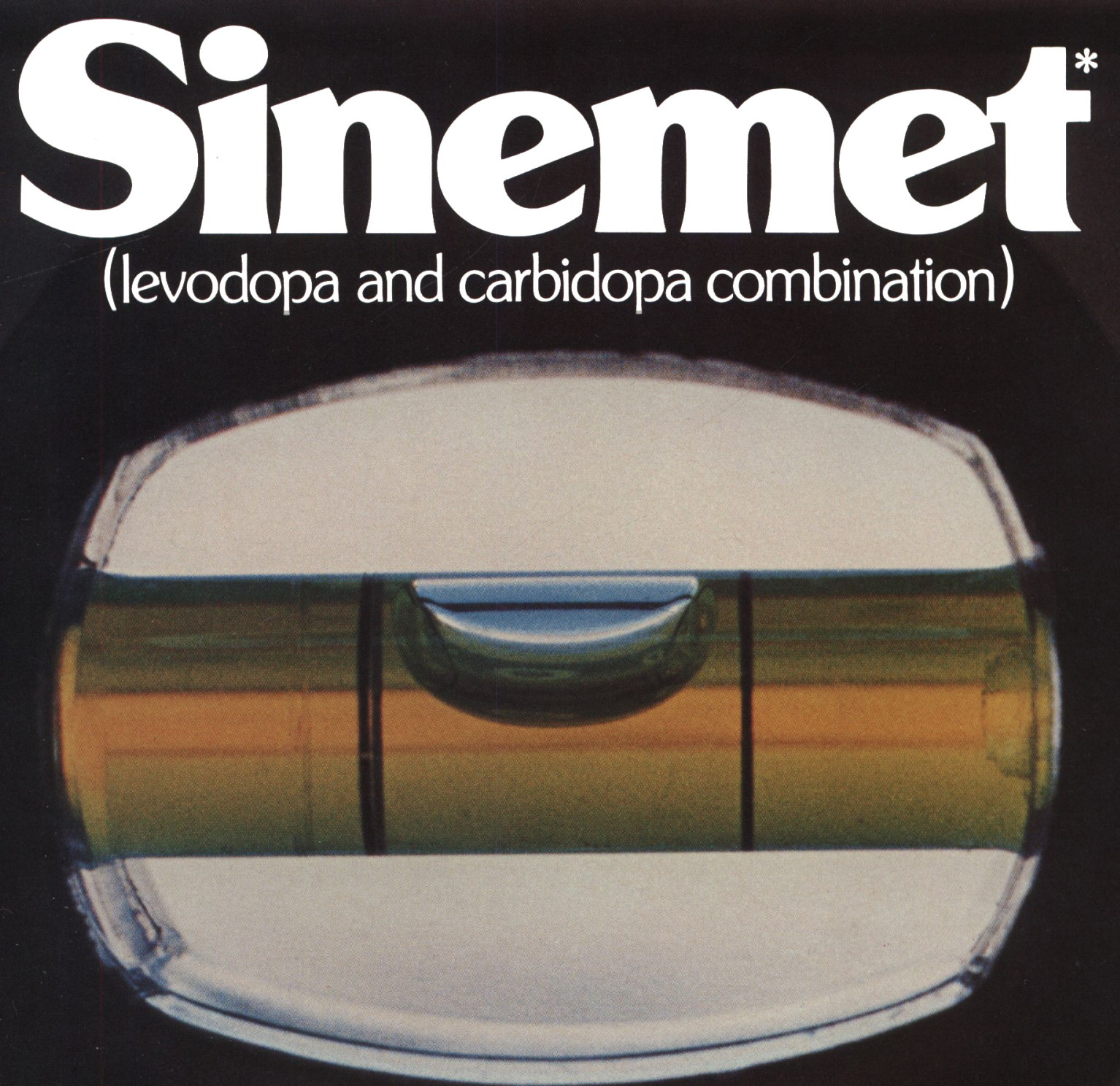

Helps restore the equilibrium of dopamine/acetylcholine in the parkinsonian patient by efficiently increasing the cerebral supply of dopamine

In most patients

SINEMET* permits control of the major symptoms particularly rigidity and bradykinesia, and helps reduce or eliminate peripheral levodopa side effects. Thus, SINEMET* enables patients to lead

more productive lives.

SINEMET* offers prompt therapeutic response-optimum dosage can usually be achieved within 2-3 weeks.

To bring the world of the parkinsonian patient back into balance 
Sinemet

ANTIPARKINSON AGENT

Common adverse reactions that can occur with SINEMET* are abnormal involuntary movements and, less frequently, mental changes. These usually can be diminished by dosage reduction.

INDICATIONS

Treatment of Parkinson's syndrome with exception of drug induced parkinsonism.

\section{CONTRAINDICATIONS}

When a sympathomimetic amine is contraindicated; with monoamine oxidase inhibitors. which should be discontinued two weeks prior to starting SINEMET*: in uncompensated cardiovascular, endocrine, hematologic, hepatic, pulmonary or renal disease; in narrowangle glaucoma; in patients with suspicious, undiagnosed skin lesions or a history of melanoma.

\section{WARNINGS}

When given to patients receiving levodopa alone, discontinue levodopa at least 12 hours before initiating SINEMET* at a dosage that provides approximately $20 \%$ of previous levodopa.

Not recommended in drug-induced extrapyramidal reactions; contraindicated in management of intention tremor and Huntington's chorea.

Levodopa related central effects such as involuntary movements may occur at lower dosages and sooner, and the 'on and off' phenomenon may appear earlier with combination therapy.

Monitor carefully all patients for the development of mental changes, depression with suicidal tendencies, or other serious antisocial behaviour.

Cardiac function should be monitored continuously during period of initial dosage adjustment in patients with arrhythmias.

Upper gastrointestinal hemorrhage is possible in patients with history of peptic ulcer.

Safety of SINEMET * in patients under 18 years of age not established.

Pregnancy and lactation: In women of childbearing potential, weigh benefits against risks. Should not be given to nursing mothers. Effects on human pregnancy and lactation unknown.

\section{PRECAUTIONS}

General: Periodic evaluations of hepatic hematopoietic, cardiovascular and renal function recommended in extended therapy. Treat patients with history of convulsions cautiously. Physical Activity: Advise patients improved on SINEMET* to increase physical activities gradually, with caution consistent with other medical considerations. In Glaucoma: May be given cautiously to patients with wide angle glaucoma, provided intraocular pressure is well controlled and can be carefully monitored during therapy. With Antihypertensive Therapy: As symptomatic postural hypotension has been reported occasionally, give cautiously to patients on antihypertensive drugs, checking carefully for changes in pulse rate and blood pressure. Dosage adjustment of antihypertensive drug may be required. With Psychoactive Drugs: If concomitant administration is necessary, administer psychoactive tion is necessary, administer psychoactive
drugs with great caution and observe patients for unusual adverse reactions. With Anesthetics: Discontinue SINEMET* the night before general anesthesia and reinstitute as soon as patient can take medication orally.

\section{ADVERSE REACTIONS}

Most Common: Abnormal Involuntary Move ments-usually diminished by dosage reduction-choreiform, dystonic and other involuntary movements. Muscle twitching and blepharospasm may be early signs of excessive dosage.

Other Serious Reactions: Oscillations in performance: diurnal variations, independent oscillations in akinesia with stereotyped dyskinesias, sudden akinetic crises related to dyskinesias, akinesia paradoxica (hypotonic freezing) and 'on and off' phenomenon. Psychiatric: paranoid ideation, psychotic episodes, depression with or without development of suicidal tendencies and dementia. Levodopa may produce hypomania when given regularly to bipolar depressed patients. Rarely convulsions (causal relationship not established). Cardiac irregularities and/or palpitations. orthostatic hypotensive episodes, anorexia nausea, vomiting and dizziness.

Other adverse reactions that may occur: Psychiatric: Increased libido with serious antisocial behaviour, euphoria, lethargy, sedation, stimulation, fatigue and malaise, confusion insomnia, nightmares, hallucinations and delusions, agitation and anxiety. Neurologic: ataxia, faintness, impairment of gait, headache increased hand tremor, akinetic episodes, "akinesia paradoxica" increase in the frequency and duration of the oscillations in performance, torticollis, trismus, tightness of the mouth, lips or tongue, oculogyric crisis, weakness, numbness, bruxism, priapism. Gastrointestinal: constipation, diarrhea, epigastric and abdominal distress and pain. flatulence; eructation, hiccups, sialorrhea; difficulty in swallowing, bitter taste, dry mouth; duodenal ulcer; gastrointestinal bleeding; burning sensation of the tongue. Cardiovascular: arrhythmias, hypotension, non-specific ECG changes, flushing, phlebitis. Hematologic: hemolytic anemia, leukopenia, agranulocy tosis. Dermatologic: sweating, edema, hair loss pallor, rash, bad odor, dark sweat. Musculoskeletal: low back pain, muscle spasm and twitching, musculoskeletal pain. Respiratory: feeling of pressure in the chest, cough, hoarseness, bizarre breathing pattern, postnasal drip Urogenital: urinary frequency, retention, incontinence, hematuria, dark urine, nocturia, and one report of interstitial nephritis. Specia Senses: blurred vision, diplopia, dilated pupils activation of latent Horner's syndrome. Miscellaneous: hot flashes, weight gain or loss. Abnormalities in laboratory tests reported with levodopa alone, which may occur with SINEMET *: Elevations of blood urea nitrogen, SGOT, SGPT, LDH, bilirubin, alkaline phosphatase or protein bound iodine. Occasional reduction in WBC, hemoglobin and hematocrit. Elevations of uric acid with colorimetric method. Positive Coombs tests reported both with SINEMET ${ }^{\star}$ and with levodopa alone, but hemolytic anemia extremely rare.

\section{DOSAGE SUMMARY}

In order to reduce the incidence of adverse reactions and achieve maximal benefit, therapy with SINEMET* must be individualized ano drug administration continuoushy matched to the needs and tolerance of the patient. Com bined therapy with SINEMET* has a narrower therapeutic range than with levodopa alone because of its greater milligram potency. Therefore, titration and adjustment of dosage should be made in small steps and recom mended dosage ranges not be exceeded. Appearance of involuntary movements should be regarded as a sign of levodopa toxicity and an indication of overdosage, requiring dose reduction. Treatment should, therefore, aim at maximal benefit without dyskinesis.

Therapy in Patients not receiving Levodopa: Initially $1 / 2$ tablet once or twice a day, increase by $1 / 2$ tablet every three days if desirable. An optimum dose of 3 to 5 tablets a day divided into 4 to 6 doses.

Therapy in Patlents receiving Levodopa:

Discontinue levodopa for at least 12 hours, then give approximately $20 \%$ of the previous levodopa dose in 4 to 6 divided doses.

FOR COMPLETE PRESCRIBING INFORMATION PARTICULARLY DETAILS OF DOSAGE AND ADMINISTRATION, PLEASE CONSULT PRODUCT MONOGRAPH WHICH IS AVAILABLE ON REQUEST.

HOW SUPPLIED

Ca8804-Tablets SINEMET* 250, dapple-blue, oval, biconvex, scored, compressed tablets coded MSD 654, each containing $25 \mathrm{mg}$ of carbidopa and $250 \mathrm{mg}$ of levodopa. Available in bottles of 100 and 500 .

* Trademark

SNM-0-596-JA

\section{MERCK}

MOVING?

PLEASE NOTIFY US OF YOUR CHANGE OF ADDRESS IN ADVANCE.

\section{PASTE OLD ADDRESS LABEL} HERE

NEW ADDRESS:

NAME:

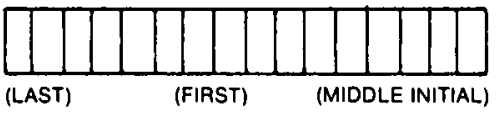

STREET ADDRESS:

PROVINCE/STATE:

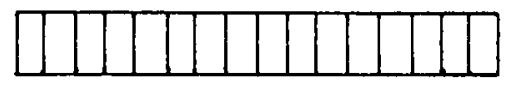

POSTAL/ZIP CODE:

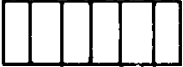

\section{MAIL TO:}

C.J.N.S.

700 William Ave., Rm. GF543

Winnipeg, Manitoba, Canada R3E 023 


\section{LE JOURNAL CANADIEN DES SCIENCES NEUROLOGIQUES}

\section{Editorial Advisory Board}

C. Miller Fisher

Boston

\section{Editorial Board}

\author{
Murray L. Barr \\ London
}

Donald W. Baxter

Montreal

Claude Bertrand

Montreal

Guy Courtois

Montreal

John G. Humphrey

Toronto

Alan J. McComas

Hamilion

\section{Associate Editor}

Andre Barbeau

Montreal

THE EDITORIAL BOARD wishes to publish original work in the basic and clinical neurosciences on the understanding that it has not been and will not be published elsewhere. Review articles on timely subjects will be accepted. Manuscripts must be in duplicate including illustrations. One of the copies must be the original, ribbon copy. Manuscripts should be typed double spaced, on white paper.

Papers will be accepted in French or English. All papers should be accompanied by a short résumé in both languages. The résumé translation will be done by the editorial board if requested.

Papers should be identified only by the full name of the author, or authors, and the name of the place in which the work was done.

ILLUSTRATIONS: Photographs should be unmounted on glossy paper and show magnification scale. They should be marked on the back with figure number, title of paper and name of author.

Diagrams should be in India ink and large enough to be informative after reduction.

All illustrations should be referred to as figures, numbered consecutively, not included in the body of the text and

\author{
J. C. Richardson \\ Toronto
}

Douglas A. McGreal

Toronto

George Monckton

Edmonton

D. G. Montemurro

London

T. P. Morley

Toronto

Dwight Parkinson

Winnipeg

J. W. Phillis

Saskatoon

Louis J. Poirier

Quebec

\section{Editor \\ R. T. Ross \\ Winnipeg}

all captions should be typed on a separate piece of paper.

Colored illustrations cannot usually be accepted unless the author is prepared to assist with the cost of reproduction.

REFERENCES to authors outside the context of the sentence should read (Name, Year). i.e. "However, a recent study (Bird and Iverson, 1975) showed a decreased, etc." Authors mentioned within the context of the sentence should read Name (Year). "i.e. ... twenty years since Ecker and Reimenshender (1951) demonstrated, etc." References should be typed in alphabetical order on a separate sheet and include author's name, initials, year, title, publication, volume, first and last page, i.e. Isacson, P. (1967). Myx-oviruses and autoimmunity. Progress in Allergy, 10, 256-292. Abbreviations should be the same'as those used in Cumulated Index Medicus.

Textbook references should include name of text, author's name, page number, publisher and city.

REPRINTS: Fifty reprints will be supplied free if ordered when the galley proofs are returned. More may be ordered at a nominal charge. Corrections and changes in the galley proofs, apart from printer's errors may be charged to the author.
Donald B. Tower

Bethesda

\author{
T. B. Rasmussen \\ Montreal \\ Neil B. Rewcastle \\ Toronto \\ J. C. Szerb \\ Halifax \\ Margaret W. Thompson \\ Toronto \\ Juhn A. Wada \\ Vancouver \\ Leonhard S. Wolfe \\ Montreal
}

\section{Editorial Assistant \\ Angela B. Ross \\ Winnipeg}

This journal is indexed by Index Medicus, Excerpta Medica and Current Contents - Clinical Practice and Life Science.

SUBSCRIPTIONS: This journal is issued four times a year. The annual rate is $\$ 24.00$ for Canada and the U.S.A., $\$ 26.00$ elsewhere. Internes, Residents, Preand Post-Doctoral Students, $\$ 12.00$ per annum. Single copies $\$ 10.00$ each.

ADVERTISING: Enquiries regarding advertising space and rates should be directed to LEX LTD. VANCO PUBLICATIONS, 190 Main Street, Unionville, Ontario L3R 2G9. Telephore - (416) 297-2030.

All communications, manuscripts, subscriptions, etc., should be sent to the Editor, at 700 William Avenue, Room GF543, Winnipeg, Manitoba R3E $0 Z 3$ Canada.

COPYRIGHT $\odot 1980$ by THE CANADIAN JOURNAL OF NEUROLOGICAL SCIENCES INC. No part of this journal may be reproduced in any form without the prior permission of The Canadian Journal of Neurological Sciences.

Printed by Lawson Graphics Ltd., 708 Moray Street

Winnipeg, Manitoba R3J 359.

Mailed under second class registration number 3307. Postage paid at Winnipeg, Manitoba. 


\section{atain}
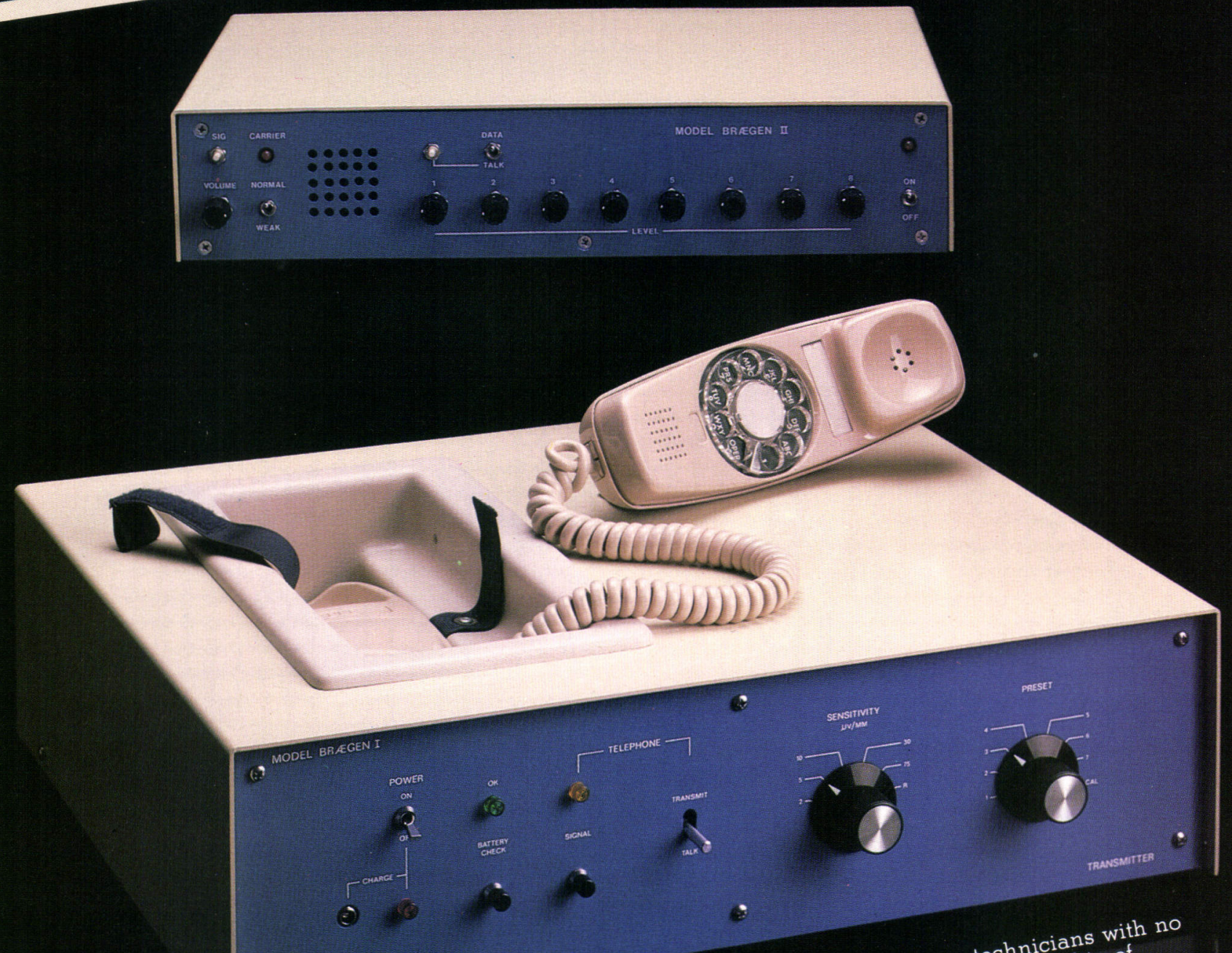

EEG Transmission Compare Braegen's Portable Look at the guality and lo System with any othink you w at the price. Wystem features: prised. Our system fea 1. BUILT-IN TELEP over a single convent the unit in. EEG transmission ov required. Just plug which you seNo special coupling

2. CUSTOM PRE-SEuirements. lect to your exact reduIIITY will all standard 3. TOTAL COMPATB brough battery writers. 4. COMPLE lightweight

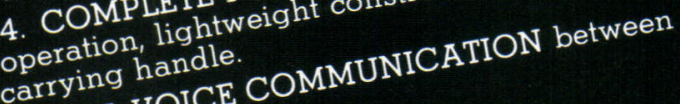
Carrying handCE COMMUNICATION between transmitting and receivint or the quality disturbance to the patient or system allows you in transmission. Braegen's sta location whil You save timer regto remain in one or clinics. to remaing hospitals or for additionaly be trained to savoutlying no need fol can easition to this cost travel wical personnent. In addition render the finest the ular clinical puipment. In will render and still at the operate the equipur system youlable... anformation and ing efficiency, transmission ar further quality of transle price. For or write: most affordabochure call or SERVICES, INC illustrated broch.MEDICAL SITE 701,

EIECTRO-BIO-N PLAZA, SUIO2

LLE HALIIDIE PLCA 94102 . $340-924$

ONE HALNCISCO, TELEX 340 SAN FRAT) 986 


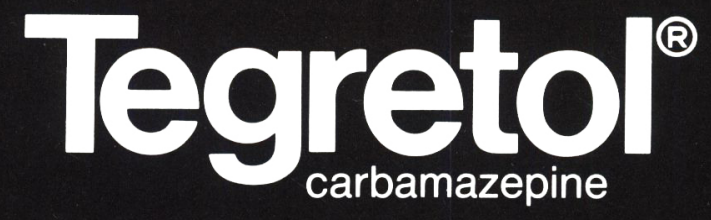

\title{
To help control refractory generalized tonic-clonic seizures
}

\author{
without excessive sedation
}

\begin{abstract}
000000
00000000000000

00000000000000

000000000000000

000000000000000

000000000000000000

000000000000000000000000

0000000000000000000000000

0000000000000000000

o 00000000000000000000000000000

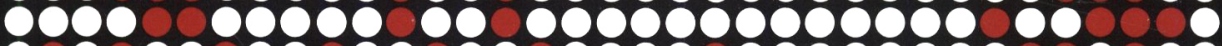

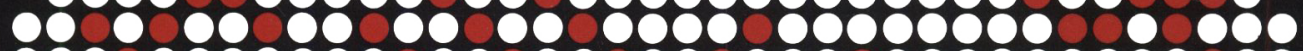

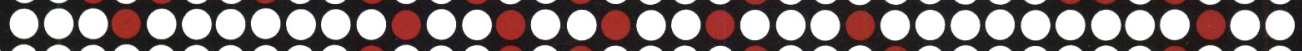

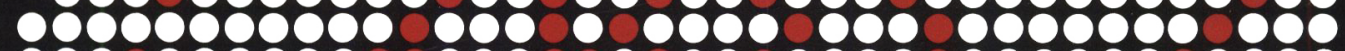

0000000000000000000000000000

000000000000000000000000

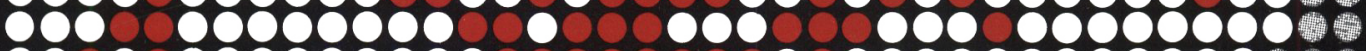

000000000000000000000000

\$

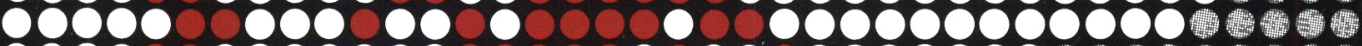

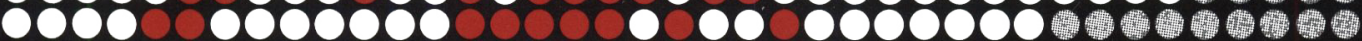

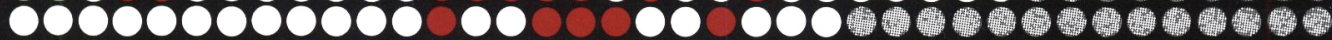

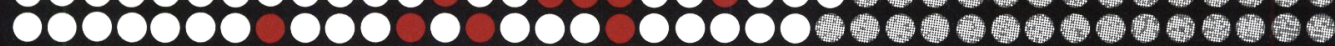

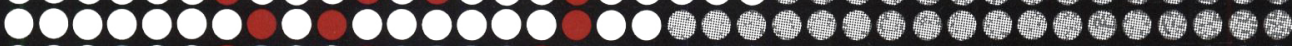

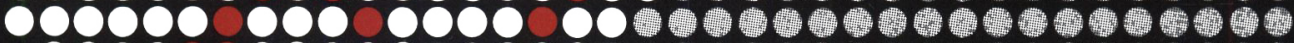

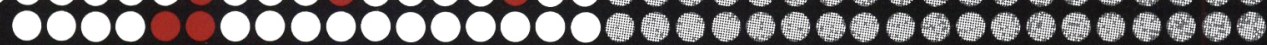

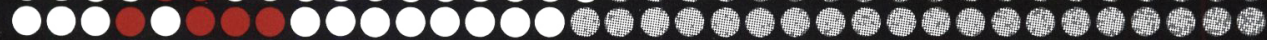

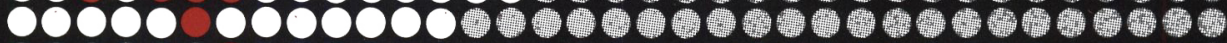

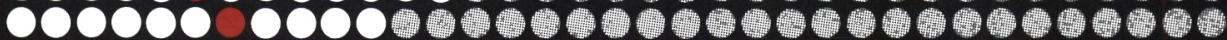

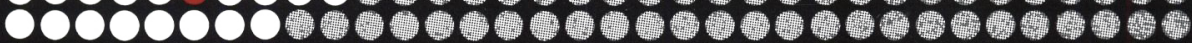
-

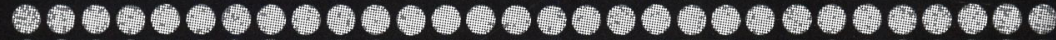

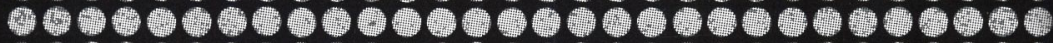

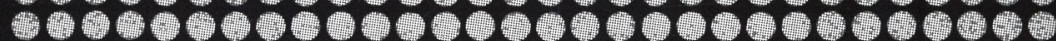

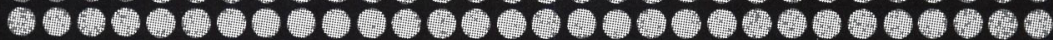

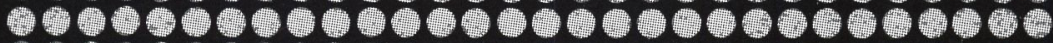

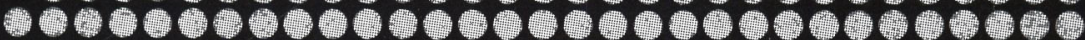

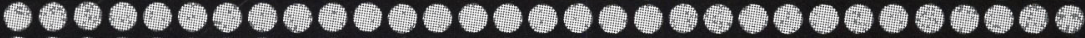

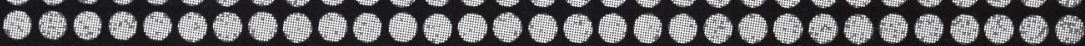

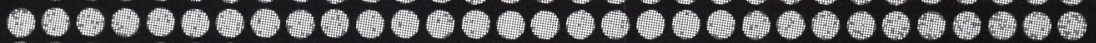

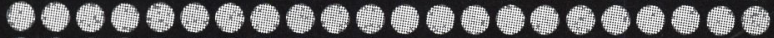

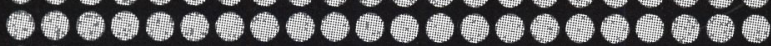

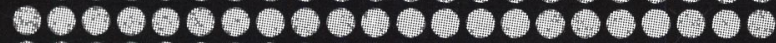

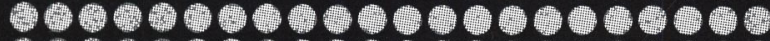

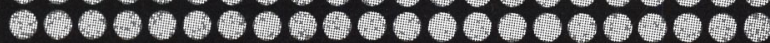

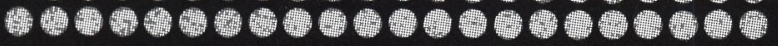


Brlet Prescribing Information

Tegreto $200 \mathrm{mg}$ carbamazepine

Indications and Clinical Use

A. Trigeminal Neuralgia:

Tegretol is indicated for the symptomatic relief of pain of trigeminal neuralgia only during periods of exacerbation of true or primary trigeminal neuralgia ( $t$ c couleureux). It should not be used preventively during periods of remission. In some patients, Tegretol has relieved glossopharyngeal neuralgia. For patients who fall to recourse to other accepted measures must be considered.

Tegretol is not a simple analgesic and should not be used to relleve trivial facial pains or headaches.

B. Tegretol has been found useful:

1) in the management of psychomotor (temporal lobe) epilepsy and,

2) as an adjunct, in some patients with secondary or pandariepsy with complex symplomatology or sec. combination with other antiepileptic medication.

3) as an alternative medication in petients with

3) as an alternative medication in patients with generalside effects or fail to respond to other anticonvulsant

side etfe

Tegretol is essentially ineffective in controlling petit

mal minor motor, myoclonic and predominantly unila-

teral seizures, and does not prevent the generalization

of epileptic discharge.

egretol should not be administered to patients with a

history of hepatic disease or serious blood disorder.

egretol should not be administered immediately

before, in conjunction with, or immediately after a mon-

oamine oxidase inhibitor. When it seems desirable to

an MAO inhibitor there should who has been receiving

an MAO inhibilor, there should be as long a drug-free

should this be less than 14 days. Then but in no case

Tegretol should be low initially, and increased very grad-

ually.

Tegretol should not be administered to patients presenting atrioventricular heart block.

Safe use in pregnancy has not been established. Therefore. Tegretol should not be administered during the

first three months of pregnancy. Tegretol should not be given to women of childbearing potential unless, in the patient outweigh the possible risk to the foetus (See patient outweigh the possible risk to the foetus (See icity in nursing animals, Tegretol should not be administered to nursing mothers.

Because of the similarity of chemical structure.

Tegretol should not be administered to patients with

known hypersensitivity to any of the tricyclic com-
pounds, such as amitriptyline, trimipramine, imipramine,

or their analogues or metabolites.

Warnings

Although reported infrequently, serlous adverse effects have been observed durlng the use of Tegretol. Agranuinstances with a fatal outcome. Leucopenla, thrombo cytopenla and hepatocellular and cholestatic laundice have also been reported. It is, therefore, important th Tegretol should be used carefully and close clinical and trequent laboratory supervision should be maln talned throughout treatment in order to detect as early as possible signs and symptoms of a possible blood dyscrasia.

Long-term toxicity studies in rats indlcated a potential carcinogenic risk. Therefore, the possible risk of drug use must be welghed against the potentlal benefits before prescribing carbamazepine to Individual patients.

Precautlons

Monitoring of Haematological and Other Adverse Reac tions: Complete blood studies, including platelet

counts, and evaluation of hepatic and renal function

and urinalysis should be carried out before treatment is inst tuted. Careful clinical and laboratory supervision should be maintained throughour treatment, including trequent pertormance of complete blood counts, in order to detect any early signs or symptoms of blood dyscrasia. Should any signs or symplons or abnormat liver disorder occur, Tegretol should be immedlately continued until the Tegretol should be immediately disUrinary Retention and increased intraocular Press

Because of its anticholinergic action. Tegret Because or its anticholncreased iniraocular Pregs should be given cautiously. if at all, to patients with increased intraocular pressure or urinary retention. Such patier closely related to the other tricyclic drugs, there is some possibility that Tegretol might activate a laten psychosis, or, in elderly patients, produce agitation or confusion, especially when combined with other drugs. Caution should also be exercised in alcoholics. Use in Patients with Cardiovascular Disorders: Tegreto should be used cautiously in patients with a history of coronary artery disease, organic heart disease, or congestive failure. If a defective conductive system is suspected, an E.K.G. should be periormed before administering Tegretol, in order to exclude patients with

atrioventricular block.

Use in Patients taking Oral Contraceptives: In women under treatment with Tegretol, the reliability of oral contraceptives may be adversely affected; such patients should accordingly be advised to use some alternative. non-hormonal method of contraception.

Driving and operating Hazardous Machinery: Because dizziness and drowsiness are possible side effects of Tegretol, patients shoud be warned about the possible hazards of operating machinery or driving automobiles. Adverse Reactions

The reactions which have been most frequently

reported with regretol are drowsiness, unsteadiness on ances, and nausea. These, gastrointestinal disturb- during the initial phase of therapy. They have rarely ecessitated discontinuing Tegretol therapy, and can The The more serious adverse reactions observed are the haer rologic, hepatic, cardicusection and dermatotherapy.

The following adverse reactions have been reported: Haematological reactions: Transitory leucopenia, Haematological reactions: Transitory leucopenia,
eosinophilia, leucocytosis, thrombocytopenic purpura, agranulocytosis, macrocytic anemia and aplastic anemia. In a few instances, deaths have occurred. Hepatic disturbances: During the long-term administration of Tegretol, abnormalities in liver function tests and cholestatic or hepatocellular jaundice have been observed.

Dermatological reactions: The following reactions

occurred during treatment with Tegretol: skin sensi-

tivity reactions and rashes, erythematous rashes, pru-

ritic eruptions, urticaria, photosensitivity, pigmentary

changes, neurodermatitis and in rare cases Stevens-

Johnson syndrome, exfoliative dermatitis, alopecia, dia-

phoresis, erythema multiforme, erythema nodosum, and

aggravation of disseminated lupus erythematosus. occurring during treatment with Tegretol include vertigo somnolence, disturbances of coprdination confusion, headache, fatigue, blurred vision, transient diplopia and oculomotor disturbances, speech disturbances, abnormal involuntary movements and increase in motor seizures. In addition, peripheral neuritis and paresthesia, depression with agitation, talkativeness, paresthesia, depression with agitation, talkativeness, very rarely. There have been some reports of paralysis very rarely. There have been some reports of paralysis but no conclusive relationship to the administration Tegretol could be established.

Cardiovascular systems: Recurrence of thrombophlebitis in patients with a prior history of thrombophlebitis congestive heart failure, aggravation of hypertension, syncope and in patients with AV block, hypotension, artery disease. Some of these complications (including myocardiat infarction and arrhythmia) have been associated with other tricyclic compounds.

Genitourinary reactions: Urinary frequency, acute urinary retention, oliguria with elevated blood pressure, and impotence. Elevation of BUN, albuminuria and

glycosuria also have been observed.

Digestive tract: Disturbances associated with Tegretol therapy have included nausea, vomiting, gastric or abdominal discomfort, diarrhoea, ancrexia and dryness of the mouth and throat, glossitis and stomatitis. Eyes: There is no conclusive evidence that Tegretol produces pathological changes in the cornea, lens or retina. However, it should be recognized that many phenothiazines and related drugs have been shown to cause eye changes. By analogy, periodic eye examinations, including slitlamp fundoscopy and tonometry, are recommended.

Other reactions reported during treatment with Tegretol include fever and chills, lymphadenopathy, aching joints and muscles, leg cramps and conjunctivitis.

\section{Dosage and Administration}

Use in Epilepsy (see Indications): A low initial daily dosage with a gradual increase in dosage is advised. Dosage should be adjusted to the needs of the individual patien

Adults and Children over 12 years of age: Initially, 100 to $200 \mathrm{mg}$ once or twice a day depending on the sever ity of the case and previous therapeutic history. The initial dosage is progressively increased, until the best response is obtained, up to $600 \mathrm{mg}$ daily. The usua optimal dosage is $600 \mathrm{mg}$ daily, but occasionally dosages up to 800 to $1000 \mathrm{mg}$ have been used for short periods. As soon as disappearance of seizures has reduced very gradually until a minimum effective dose in reached.

Uso in trigeminal nouralgia: The inilat daly dose Use in-trigeminal nouralgia: The initial daily dosage
should be small; $200 \mathrm{mg}$, taken in two doses of $100 \mathrm{~m}$ each is recommended. The total daily dosage can be increased by $200 \mathrm{mg}$ per day until relief of pain is obtained. This is usually achieved at a dosage between 200 and $800 \mathrm{mg}$ daily, but occasionally up to $1200 \mathrm{mg}$ per day may be necessary. As soon as relief of pain has been obtained and maintained, progressive reduction in dosage should be attempted until a minimum effective dosage is reached. Because trigeminal neuratgia is characterized by periods of remission, attempts should be made to reduce or discontinue the use of Tegretol at intervais of not more than 3 months, depending upon the individual clinical course.

Prophylactic use of the drug in trigeminal neuralgia is not recommeded.

Tegretol should be taken in two or three divided doses daily, with meals whenever possible.

Dosage Forms

Tegretol is available as a $200 \mathrm{mg}$ white, round, flat. bevelled-edged, double-scored tablet, imprinted with the GEIGY monogram.

Bottles of 50 and 500 tablets. Protect from heat and humidity.

Full information available on request

See outside back cover

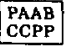

Geigy
Dorval, Qué. H9S 1B1

\section{this publication is available in microform}

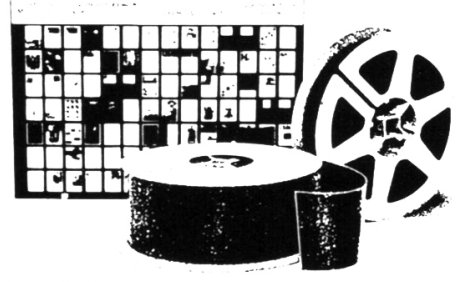

Please send me additional information. University Microfilms International 300 North Zeeb Road Dept.P.R

Ann Arbor, MI 48106

18 Bedford Row U.S.A.

London, WC1R 4EJ

England

Name

Institution

Street.

City

State

Zip 


\section{Just Another Uneventful Day.}

\section{Thanks to DILANTIN (phenytoin)}

from Parke-Davis.

For more than a generation DILANTIN has been considered the mainstay in the treatment of tonic-clonic (grand mal) seizures. When plasma levels are monitored to achieve correct dosage levels, DILANTIN alone is effective therapy for up to $90 \%$ of epileptic patients. ${ }^{*}$

Alsoavailable ZARONTIN (ethosuximide)... drug of choice** for absence (petit mal) seizures, proven to effectively control $81 \%$ of absence seizures. ${ }^{* * *}$

A continuing Medical Educational Program entitled "Seizure Disorders: Diagnosis and Clinical Management" (consisting of 2 cassette tape recordings and $20035-\mathrm{mm}$ slides) is available from Parke-

Davis. Please contact your Parke-Davis representative for availability. 


\section{DILANTIN/ZARONTIN BRIEF PRESCRIBING INFORMATION}

INDICATIONS (DILANTIN):

DILANTIN is indicated for the control of grand mal epilepsy, psychomotor seizures, and certain other convulsive disorders. Parenteral DILANTIN is indicated for the treatment of status epilepticus and the prophylactic control of seizures in neurosurgery.

\section{PRECAUTIONS AND CONTRAINDICATIONS} (DILANTIN):

Periodic examination of the blood is advisable since hematologic disorders in association with DILANTIN administration have been reported. Nystagmus in combination with diplopia and ataxia indicates dosage should be reduced. When DILANTIN with PHENOBARBITAL or PHELANTIN are used, it should be borne in mind that phenobarbital may cause drowsiness, and may be habit-forming. PHELANTIN, because of the methamphetamine content, should be given cautiously to patients with hypertension.

PHELANTIN is contraindicated in patients hypersensitive to ephedrine-like compounds; in those showing anxiety or undue excitability; and in patients with cardiac or coronary disease not likely to tolerate vasoconstrictors. The possibility of toxic effects of DILANTIN during pregnancy has not been explored.

\section{ADVERSE REACTIONS (DILANTIN):}

Once proper dosage has been determined, toxic effects of DILANTIN are infrequent Minor side effects which may occur during the initial stages of therapy include gastric distress, nausea, weight loss, transient nervousness, sleeplessness, and a feeling of unsteadiness, all of which usually subside with continued use. Allergic phenomena such as polyarthropathy, fever, and skin eruptions may occur. Acute generalised morbilliform eruption with or without a temperature elevation, may occur about two weeks after treatment is begun. The dermatitis may in some instances go on to exfoliation and hepatitis may occur, contraindicating furthe therapy with DILANTIN. Eruptions usually subside when therapy is discontinued.

Gingival hypertrophy, hirsutism, and excessive motor activity are occasionally encountered, especially in children adolescents, and young adults. Only occasionally is it necessary to discontinue DILANTIN because of these manitestations. Gingival hypertrophy can be greatly minimized by scrupulous daily care of gums and prophylactic dental care.

Megaloblastic anemia and macrocytosis have been reported but have responded to antianemic therapy. Leukopenia, granulocytopenia, thrombocytopenia, pancytopenia, aplastic anemia, and agranulocytosis have also been reported. Usually these patients were simultaneously receiving other drugs. Lupus erythematosus and erythema multiforme have occurred in patients receiving DILANTIN.

DOSAGE AND ADMINISTRATION (DILANTIN):

In all cases, optimal dosage of DILANTIN must be determined by trial. Dosage in excess of the minimum required to prevent convulsions is not recommended. For most patients, DILANTIN CAPSULES, $100 \mathrm{mg}$ or DILANTIN CAPSULES, $30 \mathrm{mg}$ are suitable for administration.

FORMS AVAILABLE:

In order to provide versatile therapy, DILANTIN is supplied in the following convenient product forms: DILANTIN` CAPSULES, $100 \mathrm{mg}$ (Cap 362). Each white capsule with orange cap contains phenytoin sodium $100 \mathrm{mg}$.

DILANTIN» CAPSULES, $30 \mathrm{mg}$ (Cap 365). Each white capsule with pale pink cap contains phenytoin sodium $30 \mathrm{mg}$.

DILANTIN® INFATABS, $50 \mathrm{mg}$. Each triangular shaped grooved tablet contains $50 \mathrm{mg}$ phenytoin INFATABS are palatably flavoured tablets, intended primarily for pediatric use.

DILANTIN-125 SUSPENSION. Each $5 \mathrm{ml}$ contains $125 \mathrm{mg}$ phenytoin. DILANTIN-30 SUSPENSION Each $5 \mathrm{ml}$ contains $30 \mathrm{mg}$ phenytoin.

These are pleasantly flavoured suspensions of DILANTIN, especially adapted for pediatric use, but suitable for adolescents and adults who prefer liquid medication.

DILANTIN with $15 \mathrm{mg}$ PHENOBARBITAL CAPSULES, (Cap 375) Each white capsule with garnet cap contains $100 \mathrm{mg}$ phenytoin sodium and $15 \mathrm{mg}$ phenobarbital.
$\Leftrightarrow$ DILANTIN with 30 mg PHENOBARBITAL CAP. SULES (Cap. 531). Each white capsule with black cap contains $100 \mathrm{mg}$ phenytoin sodium and $30 \mathrm{mg}$ phenobarbital.

These combinations of DILANTIN with PHENOBARBITAL are supplied for the convenient and economical use of those patients who require combined DILANTIN and PHENOBARBITAL therapy.

(4) PHELANTIN CAPSULES (Cap. 394). Each yellow capsule contains phenytoin sodium, $100 \mathrm{mg}$ phenobarbital. $30 \mathrm{mg}$; and methamphetamine hydrochloride, $2.5 \mathrm{mg}$.

Combining these agents takes advantage of the clinically proved anticonvulsant actions of DILAN TIN and phenobarbital while the metham phetamine counteracts the sedative effects of phenobarbital.

DILANTIN AMPOULES, $100 \mathrm{mg}$ (Amp. 1488) Each $2 \mathrm{ml}$ ampoule contains $100 \mathrm{mg}(50 \mathrm{mg} / \mathrm{ml})$ phenytoin sodium ready-mixed.

DILANTIN` AMPOULES, $250 \mathrm{mg}$ (Amp. 1475). Each $5 \mathrm{ml}$ ampoule contains $250 \mathrm{mg}(50 \mathrm{mg} / \mathrm{ml})$ of phenytoin sodium ready-mixed.

\section{NDICATIONS (ZARONTIN):}

ZARONTIN is indicated for the control of petit mal epilepsy.

\section{PRECAUTIONS (ZARONTIN):}

The physician should be alert to any symptoms indicative of the following conditions which have been reported in association with the use of ZARONTIN: aplastic anemia, agranulocytosis, dermatitis, leukopenia. Periodic blood counts should be performed. The drug should be used with caution in patients with known liver or renal disease or dysfunction. Routine urinalyses and frequent liver function tests are advised. Safe use of this drug in pregnancy has not been established.

Because of the possibility of drug-induced drowsiness, operation of motor vehicles or other machinery by patients on ethosuximide therapy is not advised. ZARONTIN when used alone in mixed types of epilepsy may increase the frequency of grand $\mathrm{mal}$ attacks in some patients.

\section{ADVERSE REACTIONS (ZARONTIN):}

In 727 patients gastrointestinal side effects occurred in $12.5 \%$, central nervous system symptoms in $6.7 \%$, blood changes in $0.4 \%$, and miscellaneous side effects in $1.2 \%$. Side effects are usually mild and transient and usually subside with continued therapy. Anorexia, gastric distress, nausea, emesis, drowsiness, headache, dizziness, euphoria, and singultus have been reported. Psychiatric or psychologic aberrations, including insomnia, night terrors, inability to concentrate, motor
unrest, agitation, and aggressiveness thought to be unrest, agitation, and aggressiveness thought to be
drug-induced or exacerbated by anticonvulsant medication, were noted in a fow patients who had previously shown emotional instability. Leukopenia, agranulocytosis, and severe pancytopenia with fatal outcome have been reported in association with ethosuximide. In most cases of leukopenia the condition cleared either on reduction of dosage or discontinuation of the drug. Other reactions in which the extent of ethosuximide implication is not yet determined include myopia, rash, vaginal bleeding, swelling of the tongue, and hirsutism. One instance of temporarily elevated (3-plus) cephelin flocculation test has been reported; patient

DOSAGE AND ADMINISTRATION (ZARONTIN):

The initial dose for children under six years of age is $250 \mathrm{mg}$ (1 capsule or $5 \mathrm{ml}$ of syrup) per day; for patients six years of age and older, $500 \mathrm{mg}$ ( 2 capsules or $10 \mathrm{ml}$ of syrup) per day. The dose thereafter must be individualized according to the patient's response.

FORMS AVAILABLE:

ZARONTIN CAPSULES, $250 \mathrm{mg}$ (Cap. 237). Each soluble gelatin capsule contains $250 \mathrm{mg}$ ethosuximide.

ZARONTIN` SYRUP: Each $5 \mathrm{ml}$ contains $250 \mathrm{mg}$ ethosuximide.

Full prescribing information available on request.

PARKE-DAVIS 
Sponglform Encephalopathy of Long Duralion: A Family Study

G.P.A. Rice, D.W. Paty, M.J. Ball, R. Tatham and A. Kertesz

Glant Axonal Neuropathy: Visual and Oculomotor Deficits - T.H. Kirkham, D. Guitton and S.G. Coupland

Migraines Inhabituelles - Louis E. Roy

Bllateral Encephaloclastic Lesions in a 26 Week Gestation Fetus: Effect on Neuroblast Migration

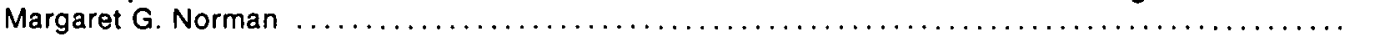

The Relatlonship Between Cerebral Blood Flow and the EEG in Normals

Devidas Menon, Zoltan Koles and Allen Dobbs

EMG Bioteedback in Patients with Motor Disorders: An Ald for Coordinating Activity in Antagonistic

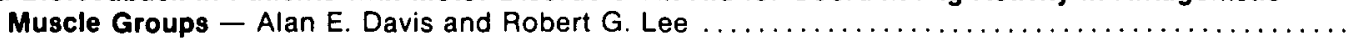

Motor Radiculopathy - An Unusual Presentation of Multiple Sclerosis

J.H. Noseworthy and L.P.M. Heffernan

University of Toronto Neurosurgical Rounds No. 3

Normal Pressure Hydrocephalus - High Pressure Normocephalus

Hart Schutz, J.F.R. Fleming, R.P. Humphreys, J.H.N. Deck and William S. Keith

Scar Prevention in Peripheral Nerve Surgery - Fraser W. Saunders

Gradient of Interference by Various Frequencies on $60 \mathrm{~Hz}$ KIndling - John Gaito

Abstracts of Third Annual Meeting of Canadian Congress of Neuropsychopharmacology

The Benzodiazepine Receptor: The Pharmacology of Emolion - H.A. Robertson

Inleractions Between the Benzodiazepines, Methylxanthines and Adenosine - J.W. Phillis and P.H. Wu

Organization of GABA-Containing Neurons In Some Extrapyramidal Nuclel - H.C. Fibiger

Use of a Synaptosomal Model to Monitor Drug-Induced In Vivo Changes in the $\gamma$-Aminobutyric

Acld Content of Nerve Endings and Its Relevance to Research on Antipsychotic Drugs - J.D. Wood

GABA and Neuropsychlatric Disorders - S.J. Enna

Trace Amines and Mental Disorders - Alan A. Bolton

Further Light on the Tyramine Test in Depression

M. Sandler, Susan Bonham Carter, M.A. Reveley, Vivette Glover and Glen Rein

Noradrenergic Function and Depression, Too Much or Too Little - J.W. Maas and Y. Huang

Pharmacokinetic Aspects of Anxiolytic Drug Therapy David J. Greenblatt \& Richard I. Shader 


\section{These minors are victims}

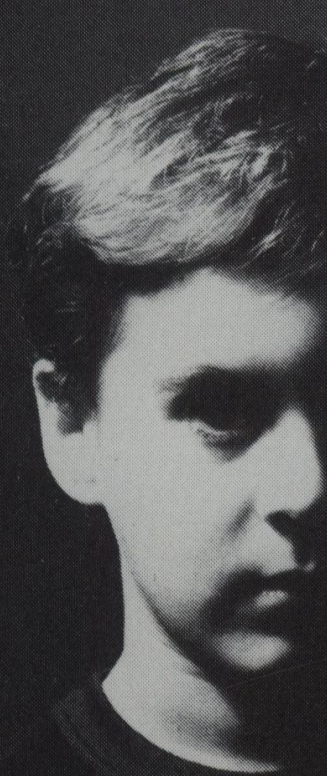

Jean - myoclonic seizures

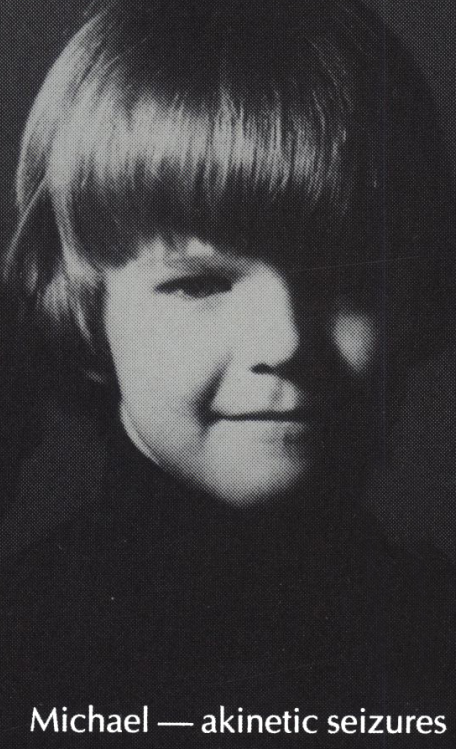

These children, victims of minor motor seizures, may benefit from the many advantages offered by 'Rivotril'.

- Effective in reducing the frequency and/or severity of a variety of epileptic seizures

- akinetic seizures

- myoclonic seizures

- Lennox-Gastaut syndrome (petit mal variant)

- absence seizures (where succinimide therapy has failed)

- flexible dosage regimen encourages patient compliance

- no reports of incompatibility with a ketogenic diet

- economical, for long-term therapy

- may be used concomitantly with most other anticonvulsants

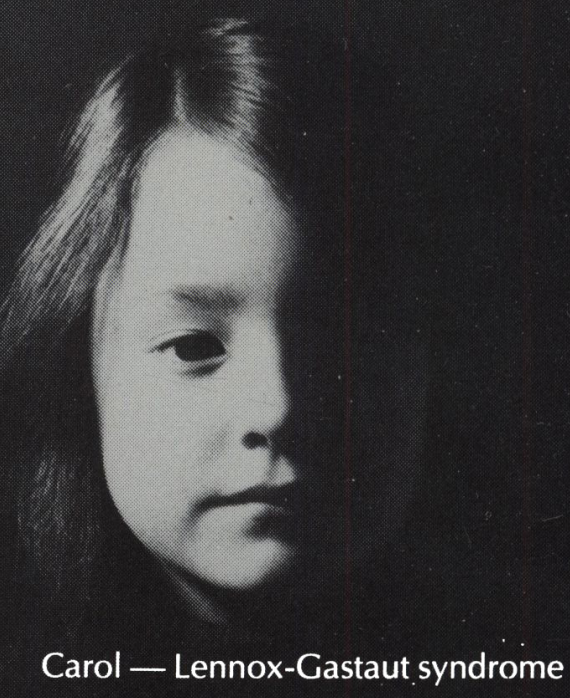

'Rivotril' has not been associated with the severe side effects seen with some other anticonvulsant medications.

- No reports of serious side effects, such as hepatotoxicity.

- Very low incidence of nausea and G.I. upsets. ${ }^{1}$

- No serious problems of drug interaction. (eg. ASA)

- Proven safety record in long-term administration.

- Drowsiness, which may occur, is generally dose-related and may be well controlled with proper dosage adjustment. 2,3 


\section{New Vira-A Parenteral}

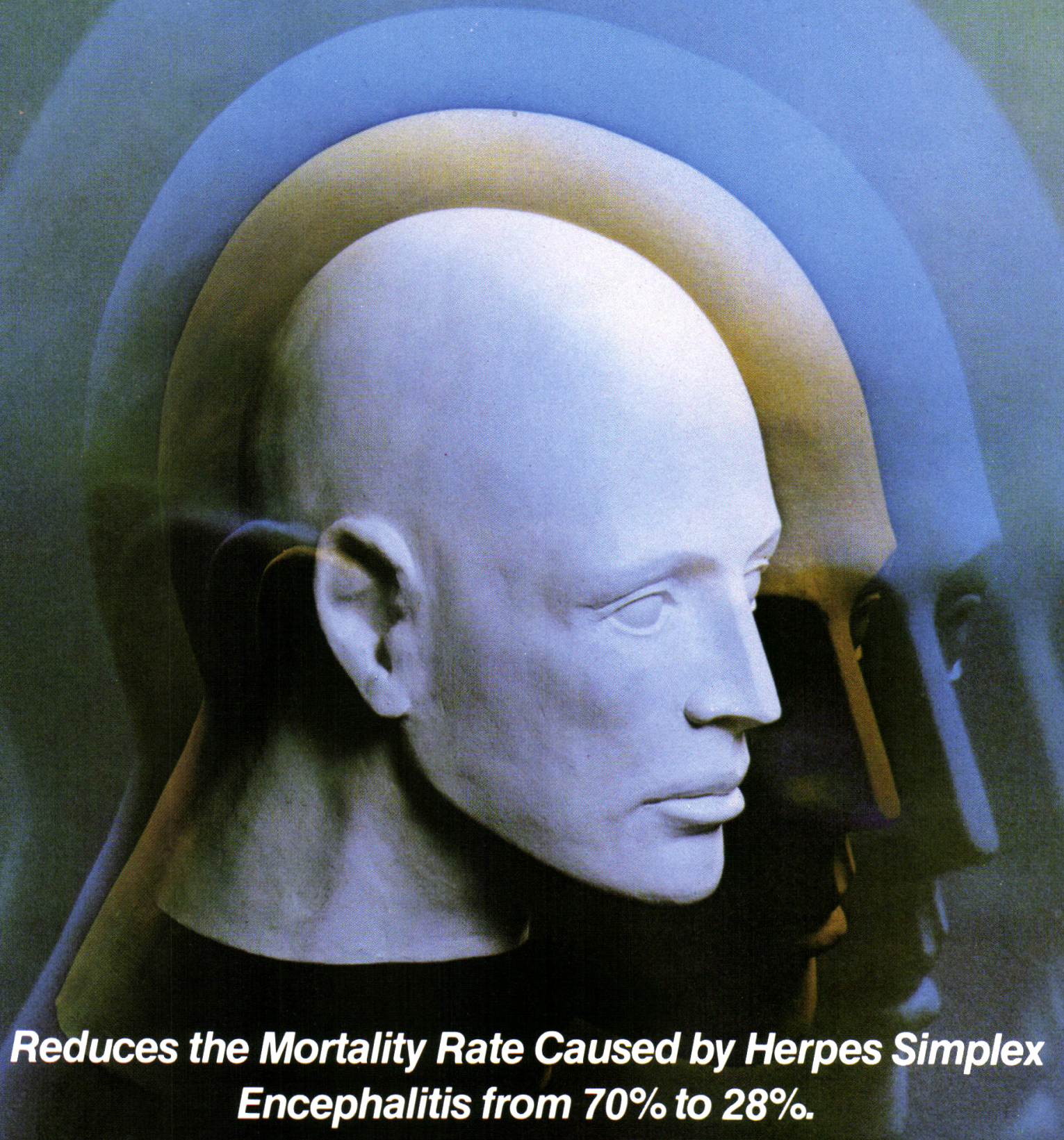

Vira-A Parenteral, a major new development from Parke-Davis Research, significantly reduces the mortality rate of patients with herpes simplex encephalitis.

In controlled studies, Vira-A Parenteral (vidarabine for infusion) reduced the mortality rate caused by herpes simplex encephalitis from $70 \%$ to $28 \%$. Over $50 \%$ of treated survivors had no or only moderately debilitating neurologic sequelae. (1)
Additional evidence suggests that Vira-A Parenteral prevents the reproduction of herpes simplex without substantial interference with the normal function of the patient's own cells. (2)

All hospital pharmacies have been provided with full prescribing information. If further information is required, contact the Medical Director, Parke, Davis and Company, Ltd.

\section{PARKE-DAVIS}


Vira-A

(Sterile Vidarabine for Infusion)

\section{PHARMACOLOGACELTIC OR Antiviral Agent}

\section{STRUCTURAL FORMULA}

ANO CHEMISTRY

Molecular Formula: $\mathrm{C}_{10} \mathrm{H}_{13} \mathrm{~N}_{5} \mathrm{O}_{4} \cdot \mathrm{H}_{2} \mathrm{O}$

Molecular Weight: 285.2

Chemical Name: 9- $\beta-D$-arabinofuranosyl-

adenine monohydrate.

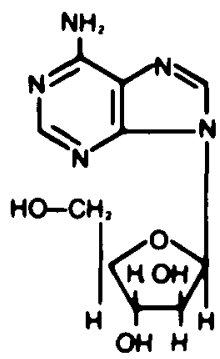

$\cdot \mathrm{H}_{3} \mathrm{O}$

Doscription: Vira-A (Vidarabine) is a white.crystalline solid. The solubility is $0.45 \mathrm{mg} / \mathrm{ml}$ at $25^{\circ} \mathrm{C}$; and the melting point ranges from $260^{\circ}$ to $270^{\circ} \mathrm{C}$.

Action. Vira-A, an antiviral drug, is a purine nucleoside obtained from fermentation cultures of Streptomyces antibioficus. Vira-A possesses in vitro and in

against Herpesvirus Simplex (Herpes Simplex virus) types 1 and 2 . The antiviral mechanism of action has not yet been established. The drug is converted into nucleotides which appear to be involved with the inhibition of viral replication. In KB cells infected with Herpes Simplex virus type 1, Vira-A inhibits viral DNA synthesis Excretion of Vira-A is principally via the kidneys. Vira-A is rapidly deaminated to $A$ ra- $H x$ (arabinosylhypoxanthine), the principal metabolite. Ara-Hx also possesses in vitro ant viral activity but this activity is significantly less than Vira-A. Forty-one to $53 \%$ of the daily dose is cumulatively recovered in the urine as $\mathrm{Ara}-\mathrm{Hx}$ with 1 to $3 \%$ appearing as the parent compound. Steady state urinary excretion of Vira-A and Ara-Hx is attained by day 3 lollowing the first infusion. The urinary excretion rate of Vira-A is generally constant over the 12 hours during infusion and the 12 hours post-infusion. There is no evidence of fecal excretion of drug or metabolite.

Indications and Clinical Use. Vira-A is indicated in the treatment of Herpes Simplex virus encephalitis. Controlled studies indicate that Vira-A therapy reduced the mortality rate due to Herpes Simplex virus encephalitis from 70 to $28 \%$

Vira-A treatment has no beneficial effect on the neurological sequelae present at the time of initiation of therapy. Therefore, early diagnosis and treatment are essential

Herpes Simplex virus encephalitis should be suspected in patients with a history of an acute febrile encephalopathy associated with disordered mentation, altered level of consciousness and focal cerebral signs.

Studies which may support the suspected diagnosis include examination of cerebrospinal fluid and localization of an "intra-cerebral lesion" by brain scan electroencephalography or computerized axial tomography (CAT).

Brain biopsy is required in order to confirm the etiological diagnosis by means of viral isolation in cell cultures.

Detection of Herpes Simplex virus in the biopsied brain tissue can also be reliably done by specific fluorescent antibody techniques. Detection of Herpes virus-like particles by electron microscopy or detection of intranuclear inclusions by histopathologic techniques only provides a presumptive diagnosis

There are no reports available to indicate that Vira-A for infusion is effective in the management of encephalitis due to varicella-zoster or vaccinia viruses. Vira-A is not effective against infections caused by adenovirus or RNA viruses. It is also not effective against bacterial or fungal infections. There are no data to support efficacy of Vira-A against cytomegalovirus, vaccinia virus, or smallpox virus.

Contraindications. Vira-A is contraindicated in patients who develop hypersensitivity reactions to it.

Warnings. Vira-A should not be administered by the intramuscular or subcutaneous route Wecause of its low solubility and poor absorption.

Precautions. Treatment should be discontinued in the patients with a brain biopsy negative for Herpes Simplex virus in cell culture, unless an obvious diagnosis of Herpes Simplex encephalitis is strongly suspected on the basis of patient history and clinical evaluation.

Special care should be exercised when administering Vira-A to patients susceptible to fluid overloading or cerebral edema. Examples are patients with CNS infections and impaired renal function.

Patients with impaired renal function, such as post-operative renal transplant recipients, may have a slower rate of renal excretion of Ara-HX. Therefore, the dose of
Vira-A may need to be adjusted according to the severity of impairment. These patients

Patients with impaired liver function should also be monitored for possible adverse
effects.

Appropriate hematologic tests are recommended during Vira-A administration since therapy. in addition to hematologic values, close monitoring of liver function, renal function, and neurological status is strongly encouraged while using Vira-A

A case of post-infectious encephalomyelitis resulting in a lasting mental impairment of the patient has been reported after an initially successful treatment of Herpes Simplex the patient has been reported after an initially successful treatment of Herpes Simplex
encephalitis with Vira-A.A Asecond course of treatment with the same drug did not alleviate the symptoms. It is important to monitor this complication in patients who survive the the symptoms. It is important to monitor this complication

Some degree of immunocompetence must be present in order for Vira-A to achieve clinical response.

Usago In Pregnancy. Vira-A given parenterally is teratogenic in rats and rabbits. Doses of Usage In Pregnancy. Vira-A given parenterally is teratogenic in rats and rabbits. Doses of
$5 \mathrm{mg} / \mathrm{kg}$ or higher given intramuscularly to pregnant rabbits during organogenesis
induced fetal abnormalities. Doses of $3 \mathrm{mg} / \mathrm{kg}$ or less did not induce teratogenic changes in pregnant rabbits. Vira-A doses ranging from 30 to $200 \mathrm{mg} / \mathrm{kg}$ were given intramuscularly to pregnant rats during organogenesis: signs of maternal toxicity were induced at doses of $100 \mathrm{mg} / \mathrm{kg}$ or higher and frank fetal anomalies, with an incidence of
$>90 \%$, were found at dose levels of $150 \mathrm{mg} / \mathrm{kg}$ and higher. Lower doses $(30.100 \mathrm{mg} / \mathrm{kg})$
had inconsistent, though positive, effects.

had inconsistent, though positive, effects. use of Vira-A in pregnant patients should be limited to life-threatening ilinesses where the possible benefits outweigh the potential risks involved.

it is not known whether Vira-A is excreted in human milk. As a general rule nursing should not be undertaken while a patient is under treatment since many drugs are excreted in human milk. However, Vira-A is rapidly deaminated in the gastro-intestinal tract.
Adverse Reactions. The principal adverse reactions involve the gastro-intestinal tract and are anorexia, nausea, vomiting, and diarrhea. These reactions are usually mild to moderate, and seldom require termination of Vira-A therapy. Occasional cases with severe discomfort requiring cessation of therapy have been reported.

Neve discomfort requiring cessation of therapy have been reported. Neurological complications have been reported at therapeutic doses. These are tremor, dizziness, hallo

psychosis, and ataxia. hemoglobin or hematocrit, total white blood cells, granulocytes and platelets. SGOT elevations were also observed. Other changes occasionally observed were decreases in reliculocyte count and elevated total bilirubin.

Other symptoms which have been reported are sharp pain of parotid or masseter muscles, weight loss, malaise, pruritus, rash, hematemesis, and pain at the injection site. Symptoms, and Treatment Of Overdosago. Acute massive overdose of the intravenous form has been reported without any serious evidence of adverse effect. Acute wate overloading would pose a greater threat to the patient than Vira-A, due to its low solubility. Doses of Vira-A over $20 \mathrm{mg} / \mathrm{kg} / \mathrm{day}$ can produce bone marrow depression with form occurs, hematologic, neurologic, liver, and renal functions should be carefully form occurs, hematologic, neurologic, liver, and renal

Acute massive oral ingestion is not expected to be toxic because drug absorption from he gastrointestinal tract is minimal. The oral LD so for Vira-A is greater than $5,020 \mathrm{mg} / \mathrm{kg}$ in mice and rats.

Dosage and Administration. CAUTION-THE CONTENTS OF THE VIAL MUST BE
DHLUTED IN AN APPROPRIATE INTRAVENOUS SOLUTION PRIOR TO ADMINISTRATION. RAPID OR BOLUS INJECTION MUST BE AVOIDED.

Dosage. Herpes Simplex virus encephalitis $15 \mathrm{mg} / \mathrm{kg} /$ day for 10 days.

Method of Preparation. Each vial contains $200 \mathrm{mg}$ of Vira-A per $\mathrm{ml}$ ot suspension. The solubility of Vira-A in intravenous infusion ftuids is limited. Each one $\mathrm{mg}$ of Vira-A requires 2.22 mive intravenous infusion luid lor complete solubilizalion. Therelore. each on intravenous infusion fluid will solubilize a maximum of $450 \mathrm{mg}$ of Vira* $A$.

The following intravenous infusion fluids are compatible with Vira-A and may be used as<smiles>[AsH2]</smiles>

$5 \%$ Dextrose injection USP

$5 \%$ Dextrose plus $0.9 \%, 0.33 \%$ or $0.45 \%$ sodium chloride injection USP or

Biologic or colloidal fluids (e.g., blood products, protein solutions, etc.) are not suitable as diluents.

Shake the Vira-A well to obtain a homogeneous suspension before measuring and transferring.

Prepare the Vira-A solution for intravenous administration by aseptically transferring the proper dose of Vira-A into an appropriate intravenous infusion fluid. The intravenous infusion fluid used to prepare the Vira-A solution may be prewarmed to $36^{\circ}$ to $40^{\circ} \mathrm{C}\left(95^{\circ}\right.$ to $100^{\circ} F$ to facilitate solution of the drug following its transference. Depending on the dose to be given, more than one litre of intravenous infusion fluid may be required. Thoroughly agitate the prepared admixture until completely clear. Complete solubilization of the drug. as indicated by a completely clear solution, is ascertained by careful visual inspection. Final filtration with an in-line membrane filter $10.45 \mu$ pore size or smaller) is necessary. Dilution should be made just prior to administration and the solution should be used within 48 hours. Any unused portion should be discarded.

Administration. Using aseptic technique, slowly infuse the total daily dose by intravenous

Availability. Vira-A (Vidarabine for infusion), a sterile suspension containing $200 \mathrm{mg} / \mathrm{ml}$ is supplied in $5 \mathrm{ml}$ Steri-Vials; packages of 10.

Animal Toxicology

Acute Toxicity. The intraperitoneal LDso for Vira-A ranged from 3,890 to $4,500 \mathrm{mg} / \mathrm{kg}$ in mice, and from 2,239 to $2,512 \mathrm{mg} / \mathrm{kg}$ in rats, suggesting a low order of toxicity to a single parenteral dose. Hepatic megalocytosis was observed in rats after single, intraperitoneal injections at doses near and exceeding the $L D_{s 0}$ value. The hepatic megalocytosis
appeared to regress over several months. Acute intravenous LDso values could not be appeared to regress over several months. Acute intrav

Subacule Toxicity. Rats, dogs, and monkeys have been given daily intramuscula injections of Vira-A as a $20 \%$ suspension for 28 days. These animal species showed dose related decreases in hemoglobin, hematocrit, and lymphocytes. Bone marrow depression was also observed in monkeys. Except for localized, injection-site injury and tolerated daily doses up to $50 \mathrm{mg} / \mathrm{kg}$. Megalocytosis was not seen in the rats dosed by the intramuscular route for 28 days.

in rats, all drug-treated males and the high and mid-dose females had moderate to marked increase in spleen weight at the end of the treatment period.

Rhesus monkeys were particularly sensitive to Vira-A. Daily intramuscular doses of 15 $\mathrm{mg} / \mathrm{kg}$ were tolerable, but doses of $25 \mathrm{mg} / \mathrm{kg}$ or higher induced progressively severe clinical signs of CNS toxicity. Three monkeys given slow intravenous infusions of Vira-Ain
solution at a dose of $15 \mathrm{mg} / \mathrm{kg}$ daily for 28 days had no significant adverse reactions. Tumorigenicity. Chronic parenteral (IM) studies of vidarabine have been conducted in mice and rats.

In the mouse study, there was a statistically signiticant increase in liver tumor incidence among the vidarabine-treated females. In the same study, some vidarabine-treated male
mice developed kidney neoplasia. No renal tumors were found in the vehicle-treated control mice or the vidarabine-treated female mice.

In the rat study, intestinal, testicular, and thyroid neoplasia occurred with greater frequency among the vidarabine-treated animals than in the vehicle-treated controls. The increases in thyroid adenoma incidence in the high-dose $(50 \mathrm{mg} / \mathrm{kg})$ males and the low dose $(30 \mathrm{mg} / \mathrm{kg}$ ) females were statistically significant.

Hepatic megalocytosis, associated with vidarabine treatment, has been found in short and long-term rodent (rat and mouse) studies. It is not clear whether or not this represents a preneoplastic change.

Mutagenicity. Results of in vitro experiments indicate that vidarabine can be incorporated into mammalian DNA and can induce mutation in mammalian cells (mouse L 5178 Y cell line). Thus far, in vivo studies have not been as conclusive, but there is some
evidence (dominant lethal assay in mice) that vidarabine may be capable of producing mutagenic effects in male germ cells.

It has also been reported that vidarabine causes chromosome breaks and gaps when added to human leukocytes in vitro. While the significance of these eftects in terms of mutagenicity is not fully understood, there is a well-known correlation between the ability of various agents to produce such effects and their ability to produce heritable genetic damage.

\section{PARKE-DAVIS}

Parke, Davis 8 Company, Ltd., 


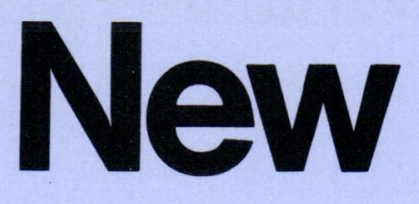

\section{baclofen}

\section{for spasticity resulting from multiple sclerosis, spinal cord injury, and spinal cord diseases.}

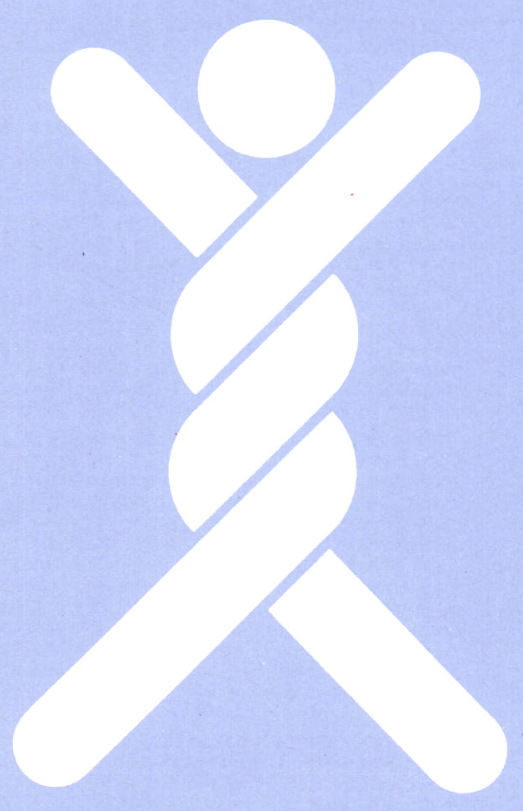

\section{Acts primarily at the spinal level}

Lioresal is capable of inhibiting both monosynaptic and polysynaptic reflexes at the spinal level, possibly by hyperpolarization of the afferent terminals. However, the precise mechanism of action is not fully known. Actions at supraspinal sites may also occur and contribute to the clinical effect. 


\section{Effective}

Results of a four-week, double blind crossover study of 22 patients showed 72 percent of 18 patients with spontaneous daytime spasms had a reduction in the frequency when treated with Lioresal. Furthermore, a reduction in severity amplitude, and duration of remaining spasms was also reported in patients treated with Lioresal. ${ }^{1}$

Figure 1. Average daily number of spasms during the last week of baclofen and placebo treatment periods in the 18 patients with spontaneous daytime spasms. (From Duncan et $\mathrm{al}^{1}$ )

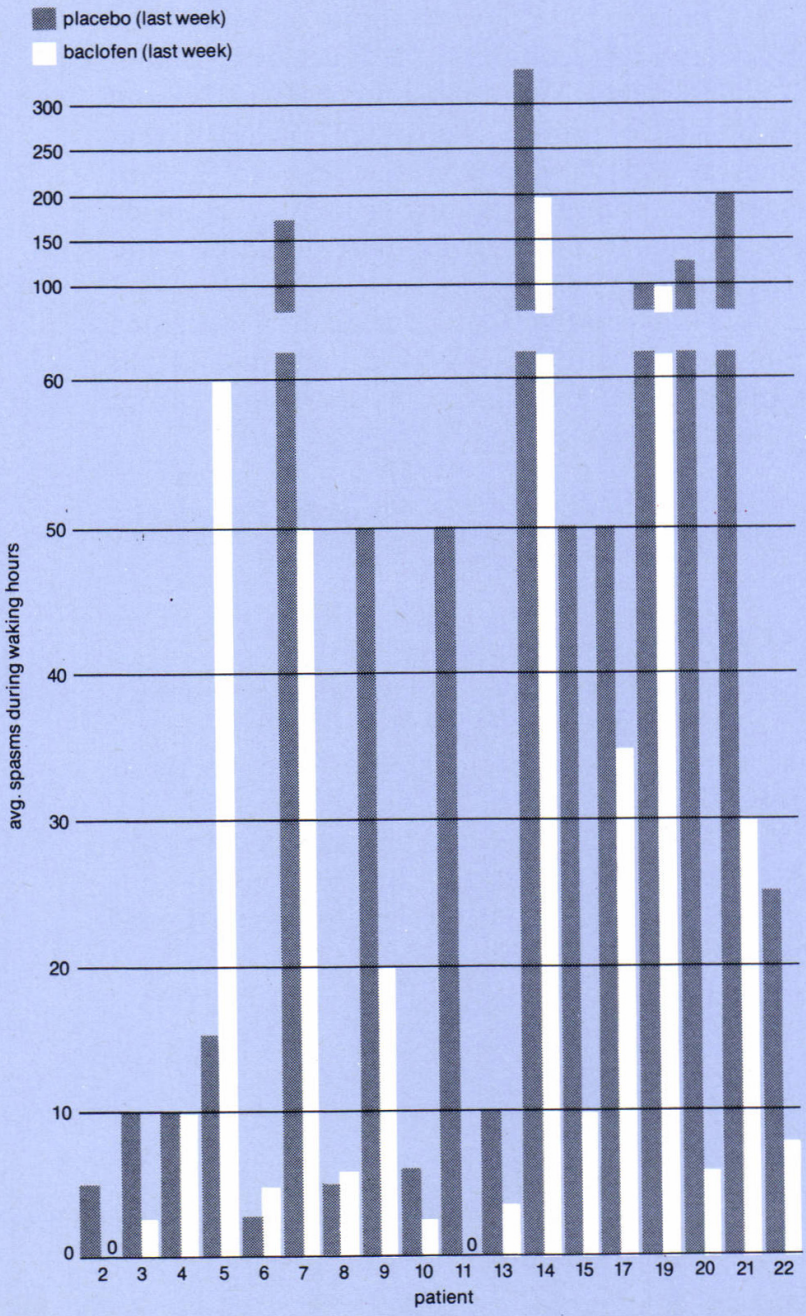

When compared with placebo and diazepam in a double-blind study, Lioresal proved to be effective in reducing the number of spasms in $50 \%$ of patients who had developed tolerance to diazepam.?

In one study of 14 patients with spasticity, "Baclofen caused less sedation than would have been expected from comparable doses of diazepam but it did nevertheless have a tranquilizing effect..."3

And in one double-blind study, "No serious side effects developed and there were no signs of even transient bone marrow, liver, kidney, or gastrointestinal toxicity." A few cases of increased SGOT, elevated alkaline phosphatase and elevated blood sugar have been reported but are not clinically significant. Gastrointestinal and other side effects also have been reported but generally do not persist.

\section{Facilitates physical therapy}

By relieving painful spasms Lioresal may allow more active physical therapy and daily function.

The advantages of improvement in resistance to passive movement noted in patients treated with Lioresal included more comfortable positioning and easier transfers and nursing.'

Effect of treatment on resistance to passive movement (Adapted from Duncan et al')

\begin{tabular}{lcc} 
Stage & Baclofen & Placebo \\
\hline Improved & $11(55 \%)$ & $1(5 \%)$ \\
Worsened & $0(0 \%)$ & $0(0 \%)$ \\
Unchanged & $9(45 \%)$ & $19(95 \%)$ \\
\hline Total & 20 & 20
\end{tabular}


Lioresal may also be of some value in patients with spinal cord injuries and other spinal cord diseases.

Contraindications

Hypersensitivity to Lloresal (baclofen)

Warnings

Abrupt Drug Withdrawal: Following abrupt withdrawal

of Lioresal (baclofen), visual and auditory hallucinations. confusion, anxiety with tachycardia and sweating

insomnia, and worsening of spasticity have occurred.

Therefore, except for serious adverse reactions, the dose

should be reduced slowly when the drug is discontinued

Impaired Renal Function: Because Lioresal is primarily

excreted unchanged through the kidneys, it should be

given with caution, and it may be necessary to reduce

the dosage. Stroke: Lloresal has not significantly bene fited patients with stroke. These patients have also

shown poor tolerability to the drug. Pregnancy: Safe use of Lloresal during pregnancy or lactation has not been established. High doses are associated with an increased incidence of abdominal hernias in the fetuses of rats and of ossification defects in those of rats and rabbits. Therefore, the drug should be administered to pregnant patients, or women of child-bearing potential only when, in the judgment of the physician, the potential benefits outweigh the possible hazards.

Precautions

Safe use of Lioresal (baclofen) in children under age 12 has not been established and it is, therefore, not recommended for use in children.

Because of the possibility of sedation, patients should be cautioned regarding the operation of automobiles or dangerous machinery, and activities made hazardous by decreased aleriness. Patients should also be cautioned that the central nervous system effects of Lioresal may be additive to those of alconol and other CNS depressants. Lioressil should be used with caution where spasticity is utilized to suslain upright posture and balance in locomotion, or whenever spasticity is utilized to obtain

Extreme caution should be exercised in patients with epilepsy or a history of convulsive disorders. In such phoulogram os as corto Caution should hally in patients laking Lloresal. caution sh with cerebrovascular disorders, and in patients palients ceiving antihypertensive therapy.

It is not known whether Lloresal is excreted in human milk. As a general rute, nursing should not be undertaken while a patient is on a drug since many drugs are excreted in human milk.

Adverse Reactions Lioresal (baclofen) are transient drowsiness, dizziness. weakness and fatigue. Others reported: Neuropsychiatric: Headache $(<10 \%)$, insomnia $(<10 \%)$, and rarely auphoria, excitement, depression, confusion, hallucina tions paresthesia muscle pain tinnitus slurred speech. coordination disorder tremor rigidity dystonia, ataxia. blurred vision nystagmus, strabismus, miosis, mydriasis, diplopia, dysarthria, epileptic seizures. Cardiovascular: Hypotension $(<10 \%)$, rare instances of dyspnea, palpitation, chest pain, syncope. Gastrointestinal: Nausea, (approx. 10\%), constipation ( $<10 \%$ ), and, rarely, $d r$ mouth, anorexia, taste disorder, abdominal pain. vomiting, diarrhea. and positive test for occult blood in stool. Genitourinary: Urinary frequency $(<10 \%)$, and, rarely, enuresis, urinary retention, dysuria, impotence. inability to ejaculate, nocturia, hematuria. Other: instances of rash, pruritus, ankle edema, excessive perspiration, weight gain, nasal congestion. Some of the CNS and genitourinary symptoms reported may be related to the underlying disease rather than to drug therapy.

The following laboratory tests have been found to be abnormal in a few patients receiving Lioresal: SGOT, alkaline phosphatase and blood sugar (all elevated). Dosage and Administration

The determination of optimal dosage of Lioresal (baclofen) requires individual titration. Start therapy at ow dosage and increase gradually until optimum effect is achieved (usually between 40-80 $\mathrm{mg}$ daily). The following dosage titration schedule is suggested: $5 \mathrm{mg}$ t.i.d. for 3 days

$10 \mathrm{mg}$ t.i.d. for 3 days

$15 \mathrm{mg}$ t.i.d. for 3 days

$20 \mathrm{mg}$ t.i.d. for 3 days The taily $80 \mathrm{mg}$ daily (20 $\mathrm{mg}$ q.i.d.)

The lowest dose compatible with an optimal response is recommended. If benefits are not evident after a reasonable trial period, patients should be slowly withdrawn from the drug (see Warnings).

Avaltability: Lioresal (baclofen) $10 \mathrm{mg}$ tablets.

Description: White to off-white flat-faced, oval tablets with Geigy monogram on one side and the identification code 23 below the monogram. Fully bisected on the reverse side. Available in bottles of 100 tablets. References

1. Duncan, G. N., Shahani, B. T., and Young, R. R.: An evaluation of baclofen treatment for certain symptoms in patients with spinal cord lesions. Neurology, (May) 1976, pp. 441-446.

2. Jones, A. F.: Lioresal in the control of spasticity. Spasticity. A topical survey, Hans Huber Publishers.

Bern, 1972, P. 113.

3. McLeilan, D. L.: Effects of baclofen upon monosynaptic and tonic vibration reflexes in patients with spasticity. J. Neurol. Neurosurg. Psychiatry, 36(4):555-560, (Aug.) 1973.

Geigy Dorval, Qué. HaS 1Bı

\section{Epilepsy International Congress - 1981}

XIV Congress of International League Against Epilepsy XIII Symposium of International Bureau for Epilepsy

Organized by:

EPILEPSY INTERNATIONAL

International League Against Epilepsy (ILAE)

International Bureau for Epilepsy (IBE)

\section{JAPAN EPILEPSY SOCIETY JAPAN EPILEPSY ASSOCIATION}

\section{INVITATION}

It is my great pleasure to extend a cordial invitation to all members of affiliated organizations of Epilepsy International as well as individuals interested in any aspect of epilepsy to attend the Epilepsy International Congress-1981.

This is the first world epilepsy congress to be held in Asia. The Congress is to meet in conjunction with the 10th International Congress of Electroencephalography and Clinical Neurophysiology (ICECN) and the 12th World Congress of Neurology (WCN), so that this Congress will serve as a bridge between the two congresses. We hope to organize a truly world-wide congress with participants from many disciplines and interests.

We sincerely hope that the Congress will be a milestone in helping people with epilepsy and that this old but new ailment will eventually be eradicated from throughout the world.

\section{Haruo Akimoto Congress President}

\section{PLACE AND DATE}

The Congress will be held from Thursday, September 17 to Monday, September 21, 1981 at the Kyoto International Conference Hall located in the northern outskirts of Kyoto City.

This Congress will therefore be a link between the 10 th ICECN (Sept. $13-18$ ) and the 12th WCN (Sept. 20 26), both to be also held at the Kyoto International Conference Hall. 


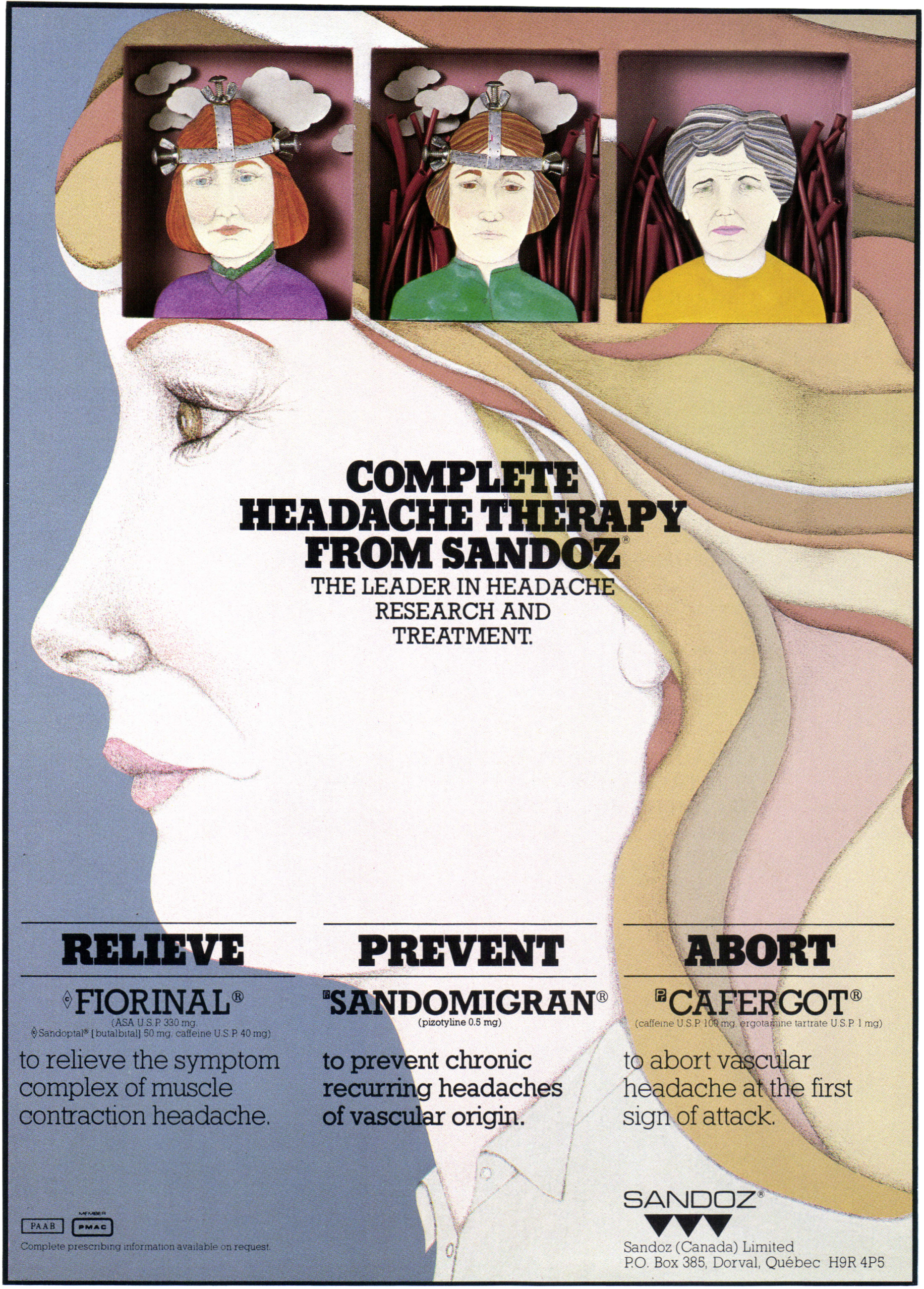


The Canadian Journal of Neurological Sciences is the official publication of the Canadian Neurological Society, the Canadian Neurosurgical Society and the Canadian Society of Electroencephalographers, and Electromyographers and Clinical Neurophysiologists.

These three Societies meet together as the Canadian Congress of Neurological Sciences once a year. The meetings are usually held in the third week in June. A different city is chosen for the meeting each year.

Details regarding membership in each of the Societies, the date and place of the meeting and the scientific program can be obtained from the Secretaries.

\title{
CANADIAN NEUROLOGICAL SOCIETY
}

$\begin{array}{lll}\text { Past President } & \text { Dr. J.R. Wherrett } & \text { Council - } \\ \text { President } & \text { Dr. A.J. Aguayo } & \text { Dr. M. Aubé } \\ \text { Vice-President } & \text { Dr. R.G. Lee } & \text { Dr. N. Lush } \\ & & \text { Dr. D. R. Mclean } \\ \text { Secretary- } & \text { Dr. Robert F. Nelson } & \text { Dr. J. Meloche } \\ \text { Treasurer } & \text { Dept. of Medicine } & \text { Dr. M.J. Newman } \\ & \text { Ottawa General Hospital } & \text { Dr. D.W. Paty } \\ & 43 \text { Bruyere St. } & \\ & \text { Ottawa K1N 5C8 } & \\ \text { Canada } & \end{array}$

\section{CANADIAN NEUROSURGICAL SOCIETY}

$\begin{array}{lll}\text { Past President } & \text { Dr. J.F.R. Fleming } & \text { Council- } \\ \text { President } & \text { Dr. G. Bertrand } & \text { Dr. G. Ferguson } \\ \text { President-Elect } & \text { Dr. P.B.R. Allen } & \text { Dr. A.A.J. Godon } \\ \text { Secretary- } & \text { Dr. F.E. LeBlanc } & \text { Dr. W.J. Howes } \\ \text { Treasurer } & \text { Foothills Hospital } & \text { Dr. A.R. Hudson } \\ & \text { Calgary, Alberta } & \text { Dr. S.T. Myles } \\ & \text { T2N 2T9 } & \text { Dr. B.K.A. Weir }\end{array}$

CANADIAN SOCIETY OF ELECTROENCEPHALOGRAPHERS, ELECTROMYOGRAPHERS AND CLINICAL NEUROPHYSIOLOGISTS

$\begin{array}{ll}\text { Past President } & \text { Dr. M. Brandstater } \\ \text { President } & \text { Dr. J. Reiher } \\ & \\ \text { Secretary- } & \begin{array}{l}\text { Dr. A. Eisen } \\ \text { Treasurer }\end{array} \\ & \text { Montreal Neurological } \\ & \text { Institute } \\ & \text { 3801 University Street } \\ & \text { Montreal, P.Q. } \\ & \text { H3A 2B4 }\end{array}$

\author{
Council - \\ Dr. C. Bolton \\ Dr. R. Broughton \\ Dr. N. Giard \\ Dr. J. Humphrey \\ Dr. W. Blume
}

